UDC 535.2; 535.3; 62-93; 620.9

\title{
DESIGNING SOLAR POWER CONCENTRATOR MODEL WITH EXTENTIONAL FOCAL ZONE
}

\author{
Ivan Zavirokhin
}

\section{Ternopil LTD scientific and technical centre «ENVOS», Ternopil, Ukraine}

\begin{abstract}
Summary. In the article, the possibility of constructing the concentrator with mirror segments joined in a circe, able to specifically create a focal area of energy concentration in the form of imaginary volume right above its opening plane is discussed. Computer simulation of distributing illumination field of certain focal planes above the opening plane of such a concentrator proved the presence of the focal area shaped in the form of an imaginary body of a particular shape and size that have to be used by placing the concentrated energy transceivers. These transceivers can have a look of a simple conical heat exchanger, multiple heat vacuum tubes with a heat exchanger, or even a specific block with many GaAs based transient cells to generate electricity. focal volume.

Key words: concentrator; segment; paraboloid cylinder-shaped; focal plane; focal concentration area;
\end{abstract}

Statement of the problem. Increase the use of light solar energy concentrated by a parabolic mirror concentrator.

Analysis of the available investigations. The main task of the concentrator is to create the maximum achievable concentration of solar energy at the receiver and the most complete use of the received one for further efficient conversion to another type of energy. Rescently, the wide known is concentration of solar energy and its focusing on the receiver by means of various parabolic mirror concentrators in order to obtain concentration in the so-called «focal point», «focal spot» or «focal line» at the receiver $[1,2,3,5,7,8,9]$. Their common disadvantage is the use of only a certain part of the focal concentration energy.

When designing solar energy concentrator, the laws of optics are taken as a basis, in which it is customary to consider and use the concept of a focal plane perpendicular to the optical axis, passes through the focus, on which a focal ellipsoid spot is formed, and it is mainly taken into account when constructing different types of receivers. However, in reality, as it is noted in [3], various errors in the manufacture of optical systems form a certain aberration and there is a so-called curvature of the image field, in other words, the image area. In optics, this phenomenon is considered negative and various means for its elimination are used.

When concentrating light solar energy, there are the angular dimensions of the light source (the Sun) and the manufacturing errors of the concentrator that cause aberration, and therefore there must also be an area of focal concentration, i. e. any imaginary «focal volume» of a certain shape and size that may cross several focal planes as particles of this volume.

The objective of the work is to achieve the maximum possible use of the whole volume of concentrated energy in the concentrator by intentionally forming an area of focal concentration in the form of an imaginary volumetric figure of a certain shape and size.

Statement of the task. For achieving this aim, the most suitable for the construction of the concentrator is the use of the concentrator of parabolic cylindrical trapezia-shaped segments joined in circle as a single concentrator whose area of focusing concentration of solar energy would be located right above its opening plane. 
Results of the research. In accordance with the task, the theoretical researches were carried out by computer simulation using SolidWork/OptisWords software (integrated environment of analysis and synthesis in illumination engineering and optics), the nature of the light field distribution of the illumination of individual focal planes crossing the focal area above the opening plane of such a concentrator. At the same time, the initial data were applied: lighting of the layout with a point light source; focal length; shape of the illuminating surface. From the several variants, the one that optimally corresponds the task was chosen. Figure 1 shows the example of a model of focal planes illumination in a section of the focal zone volume at the distance $50 \mathrm{~mm}$ respectively above the opening plane.

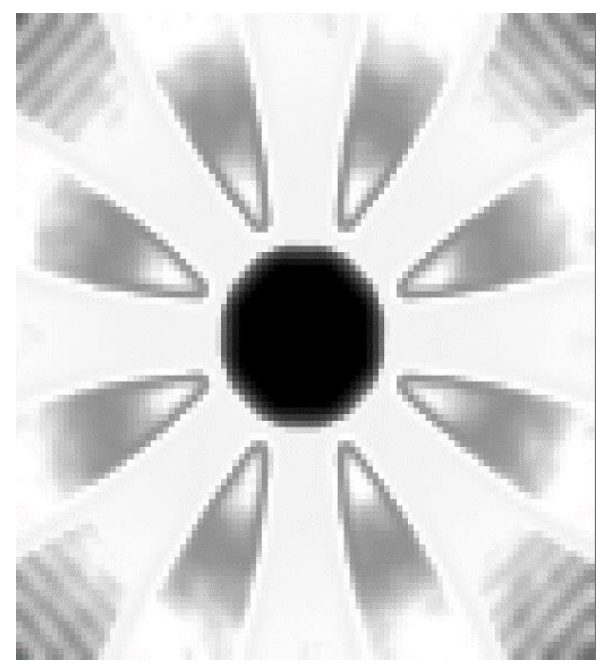

Figure 1. Model of focal plane illumination at the distance $50 \mathrm{~mm}$ above the open plane

We observe the readings of the maximum illumination zone at the ends of eight wedgeshaped sectors obtained from the parabolic cylindrical segments of the concentrator. The focus zone lays there. Black spot is a non-working area in the center of the concentrator.

Simulation of the individual focal planes illumination gives an idea of location, shape and size of the focal zone, the shape of which is reverse to the focal plane illumination shape. It is situated close above the concentrator opening plane.

High concentration begins at the level of an opening plane $0 \mathrm{~mm}$ and finishes above the opening at the distance $150 \mathrm{~mm}$.

$50 \mathrm{~mm}$ lower than the opening plane and $150 \mathrm{~mm}$ higher than the opening plane, the concentration sharply decreases. Efficient length of the focal concentration area can be practically taken as $200 \mathrm{~mm}$ and in respective way place the working area of receivertransformer there.

Due to the simulation results, the constructions of segment concentrators which consist of eight parabolic cylindrical trapezia-shaped mirror segments joined into circle were developed. In the centre of concentrator along its axis, the cone-shaped cupper energy transceiver is placed (Figure 2) with the fluid circulating in it and the working area of which is in the calculation zone of focal concentration located right above the concentrator opening area. While designing this transceiver, the methods of setting thermal conductivity and heat exchange task given in [4] were taken into account. Also, several thermal vacuum tubes with heat exchanger were used as transceiver (Figure 3). It is possible that in the future, the installation of many GaAs-based transition cells will be available for direct electricity generation. 


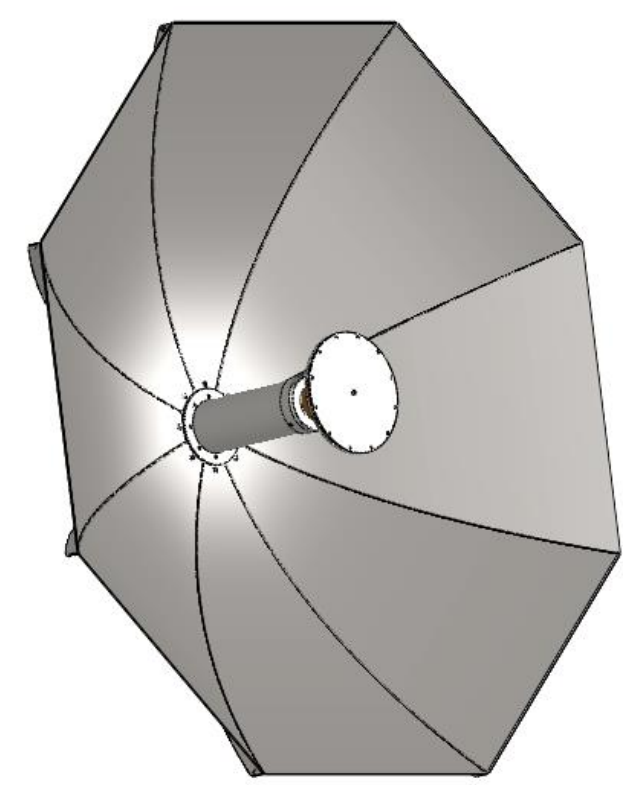

Figure 2. The appearance of the segment concentrator with cone-shaped receiver

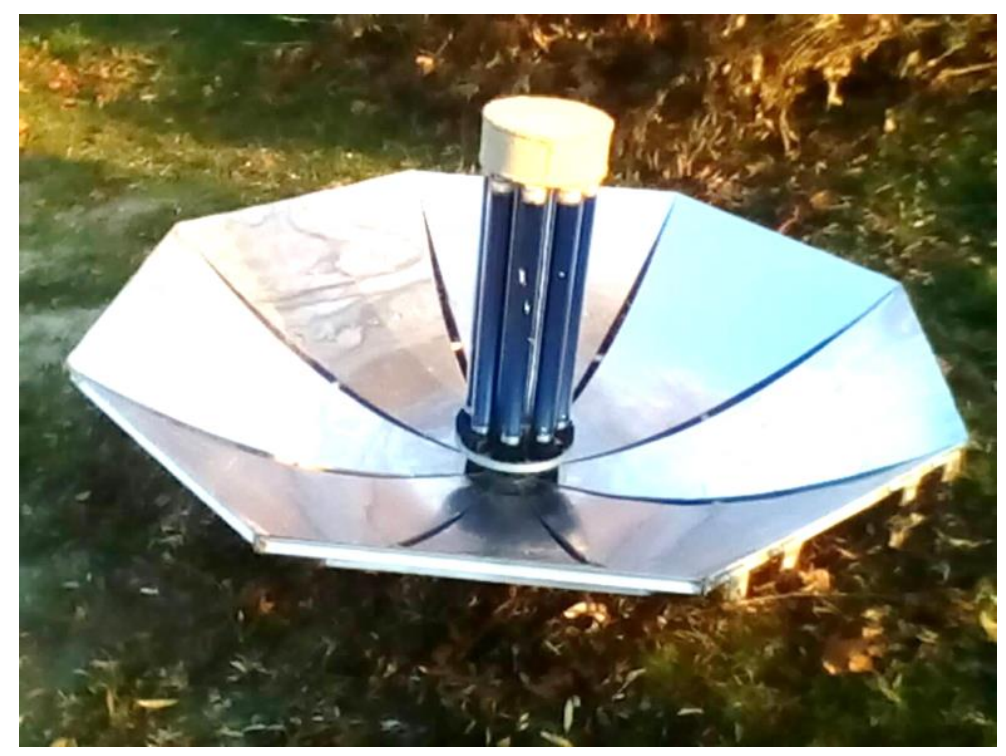

Figure 3. Segment concentrator $d=1,7 \mathrm{~m}$ with heat vacuum tubes and heat exchanger

Conclusions. Segment concentrators (Figure 2, 3) are made. Full-scale tests conducted at a favorable time of year according to the recommendations [6] proved the focal concentration area in the form of imaginary volume of a cut multifaceted oval shape at the length $200 \mathrm{~mm}$ with the internal non-functional through hole along the axis. The cut vertex have approximate dimensions $\mathrm{d} \approx 130 \mathrm{~mm}$ and the middle part $\mathrm{d} \approx 170 \mathrm{~mm}$ of the inscribed circle. The approximate area of the outer surface of such an imaginary figure to be used for energy removal is $\approx 0,08 \mathrm{~m}^{2}$. If use only the largest «focal spot» with a diameter $170 \mathrm{~mm}$, then its area is only $\approx 0,023 \mathrm{~m}^{2}$. Thus, we can have a fourfold increase in the use of concentrated solar energy by the surface of the receiver and, accordingly, increase the efficiency of the system. The inner through hole is equal to the size of the central non-reflecting part of the reflector, $d_{1}=100 \mathrm{~mm}$.

Energy efficiency concentration ratio when using mirror coated aluminum segments

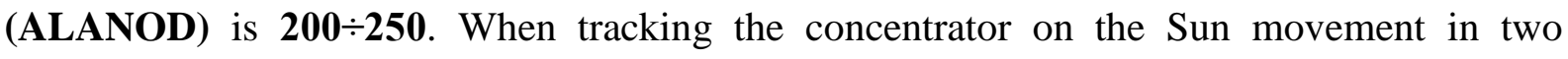


coordinates, there is a powerful concentration of solar energy on heat vacuum tubes located in two hundred millimeters' focal area, and powerful heating of the working fluid circulating in the heat exchanger.

\section{References}

1. Strebkov D. S., Tverânovič E. V. Koncentratory solnečnogo izlučeniâ. Moskva: GNU VIĖSH, 2007. Ch. 6. P. 144-179; Ch. 7. P. 180-215; Ch. 10. P. 252-254. [In Russian].

2. Parabolocilindričeskij hub solnečnoj ènergii: patent RU 2300058; publ. 27.05.2007, Bul. No. 15. [in Russian].

3. Romanyuk M. O., Kročuk A. S., Pašuk I. P. Optics. Lvov: LNU name Ivan Franko, 2012. 564 p. [In Ukrainian].

4. Popovych V., Zavodovska N. The temperature field for thermoslusitive finite cylinder under convective heat exchange with the variable temperature surroudings. Bulletin of TNTU. 2013. Vol. 72. № 4. P. 252-260.

5. Segment hub: patent for utility model UA 97781; publ. 10.04.2015, Bul. No. 7. [In Ukrainian].

6. Andriychuk V., Filyuk Y. Doslidzhennia enerhetychnoho potensialu soniachnoho vyprominiuvannia v Ternopoli. Research of energy potential of solar radiation in Ternopil. Scientific Journal of TNTU. 2017. Vol. 85. No. 1. P. 95-100. [In Ukrainian].

7. Solar module with a fixed parabola cylindrical concentrator: pat. UA 118295; publ. 25.07.2017, Bul. No. 14. [In Ukrainian].

8. The Parabola cylindrical concentrator of solar energy: pat. UA 121837; publ. 11.12.2017, Bul. No. 23. [In Ukrainian].

9. Strebkov D. S., Tverânovič E. V. Solnečnye èlektrostancii: koncentratory solnečnogo izlučeniâ:učebnoe book for vuzov, 2nd ed. / edited. D. S. Strebkova. Moskva: Ûrajt, 2019, 264 p. [In Russian].

\section{Список використаної літератури}

1. Стребков Д. С., Тверьянович Э. В. Концентраторы солнечного излучения. М.: ГНУ ВИЭСХ, 2007. Гл. 6. С. 144-179; Гл. 7. С. 180-215; Гл. 10. С. 252-254.

2. Параболоцилиндрический концентратор солнечной энергии: пат. RU 2300058; опубл. 27.05.2007, Бюл. № 15.

3. Романюк М. О., Крочук А. С., Пашук І. П. Оптика. Л.: ЛНУ ім.. Івана Франка, 2012. 564 с.

4. Попович В., Заводовська Н. Температурне поле скінченного термочутливого циліндра за конвективного теплообміну з середовищами змінних температур. Вісник ТНТУ. 2013. Том 72. № 4. C. $252-260$.

5. Сегментний концентратор випромінювання. Патент UA 97781 опубл.10.04.2015. Бюл. №7;

6. Андрійчук В. А. Дослідження енергетичного потенціалу сонячного випромінювання в Тернополі. Вісник ТНТУ. 2017. Том 85. № 1. С. 95-100.

7. Сонячний модуль зі стаціонарним параболо циліндричним концентратором: пат. UA 118295; опубл. 25.07.2017, Бюл. № 14.

8. Параболо циліндричний концентратор сонячної енергії: пат. UA 121837; опубл. 11.12.2017, Бюл. № 23.

9. Стребков Д. С., Тверьянович Э. В. Солнечные электростанции: концентраторы солнечного излучения: учебное пособие для вузов, 2-е изд. / под ред. Д. С. Стребкова. М.: Юрайт, 2019. 264 с. 


\title{
УДК 535.2; 535.3; 62-93; 620.9
}

\section{КОНСТРУЮВАННЯ МОДЕЛІ КОНЦЕНТРАТОРА СОНЯЧНОЇ ЕНЕРГІЇ З ОБ'ЄМНОЮ ФОКАЛЬНОЮ ЗОНОЮ}

\section{Іван Завірохін}

\author{
ТОВ Тернопільський науково-технічний цеентр «ЕНВОС», \\ Тернопіль, Україна
}

\begin{abstract}
Резюме. Проаналізовано фокусування різного типу параболічних концентраторів сонячної енергї, які концентрують енергію в «точковий фокус», «фокусну лінію», «фокальну пляму» й при конструюванні яких використовують і розглядають загально прийняте поняття - «фокальна площина». При наявності кутових розмірів Сонця, джерела світлової енергї $і$ різних похибках виготовлення концентратора, щзо викликають певну аберацію, виникає «кривина поля зображення» та повинна існувати область фокальної концентрації - «фокальний об'єм» певної форми й розмірів, а «фокальна плошина» $\epsilon$ його перетином (часткою), щзо використовує на приймачі лише якусь частину обсягу сконцентрованої енергї. Розглядається можливість конструювання концентратора 3 сегментоподібними параболо ииліндричними дзеркальними сегментами, з'єднаними по колу, спроможного спеціально створити область фокальної концентрації енергї у вигляді уявного об'єму відразу над площчною його розкриву. Моделювання за допомогою комп ютера характеру розподілу світлового поля освітленості окремих фокальних площин над площиною розкриву такого концентратора, підтвердило наявність області фокальної концентрації у вигляді уявного об'єму певної конфігурації $i$ розмірів, які слід використовувати розташовуючи в ньому приймачі - перетворювачі сконцентрованої енергї, щз можуть мати вигляд простого конічного теплообмінника, декількох теплових вакуумних трубок з теплообмінником або навіть певного блока з багато перехідними фотоелементами на основі GA As для отримання електроенергії. Були розроблені конструкиії і виготовлений сегментний конщентратор сонячної енергії у складі восьми секторів розташованих по колу та приймача-перетворювача у вигляді мідного конічного теплообмінника з ичркулюючою рідиною, а також концентратор з тепловими вакуумними трубками, робочі поверхні яких розташовані в області фокальної концентрації. Випробування концентраторів практично довели наявність області фокальної концентрації енергї $i$ показали збільшення обсягу ї̈ використання на приймачі.

Ключові слова: концентратор, сегмент, параболо циліндричний, фокальна площчина, область фокальної кониентрації, фокальний об'єм.
\end{abstract}

